\title{
A new record of Badhamia versicolor Lister (Physaraceae) in Poland
}

\author{
Artur Pliszko* \& Anna Bochynek
}

Institute of Botany, Jagiellonian University in Kraków, Kopernika 31, 31-501 Kraków, Poland

* corresponding author (e-mail: artur.pliszko@uj.edu.pl)

\begin{abstract}
The paper presents a new Polish record of Badhamia versicolor, a nationally rare and red-listed species of Myxomycetes. It was discovered on the edge of the disused sand and gravel pit (formerly, a gravel mine of the Polish State Railway) in the town of Suwałki, north-eastern Poland. Two small clusters of mature fruiting bodies of B. versicolor were noticed on a bark of living poplar (unidentified species of Populus) and on a fallen leaf of the same poplar tree. Photographic documentation of specimens collected from a new locality is provided.
\end{abstract}

Key words: distribution, human-made habitat, Lithuanian Lakeland, Myxomycetes, rare species

\section{Introduction}

The genus Badhamia Berk. belongs to the family Physaraceae (Myxomycetes) and comprises about 40 species (Hatano \& Keller 2008). In Poland, it is represented by 11 species (Drozdowicz et al. 2003). Badhamia versicolor Lister has a cosmopolitan range, but occurs rarely in North America, South America, Europe, Asia, Africa and Australia (Macbride 1922; Krzemieniewska 1960; Wrigley de Basanta 1998; Ranade et al. 2012; Abdel-Azeem \& Salem Fatma 2013; Moreno et al. 2013; Wellman 2015; www.discoverlife. org). It is usually found on the bark of living trees, often on mosses and lichens (Ing 1982; Poulain et al. 2011). It was also reported from the moist chamber cultures of the bark from living trees (Lado 1991; Wrigley de Basanta 1998). Badhamia versicolor resembles B. capsulifera (Bull.) Berk. and B. dubia Nann.-Bremek. in having a single peridium, however, it can be separated from these two species based on the larger clusters of spores and smaller sporocarps (Poulain et al. 2011). Moreover, the specimens with a white capillitium can be easily confused with $B$. papaveracea Berk. et Rav. (Krzemieniewska 1960), however, the latter species forms sporocarps on short stalks, whereas in $B$. versicolor, the sporocarps are sessile (Poulain et al. 2011).

The first record of $B$. versicolor in Poland was provided by Krzemieniewska (1960) based on herbarium specimen collected by Raciborski (1884). It was found in Kraków or in its environs (Małopolska Province, southern part of the country) and misidentified as B. papaveracea. The substrate on which the species was recorded is unknown (Drozdowicz et al. 2003). Badhamia versicolor is one of the rarest slime mould species in Poland and due to its rare occurrence (only one known locality) it was included in the national red list of Myxomycetes (Drozdowicz et al. 2006). In this paper, a new record of the species in Poland is presented.

\section{Material and methods}

Badhamia versicolor was identified using morphological and anatomical features given by Krzemieniewska (1960) and Poulain et al. (2011). Permanent microscope slides were made by soaking the dried material in Hoyer's medium. Microscopic examination was conducted using a stereoscopic binocular microscope and a ZEISS Axioskop 2 microscope. Spores were examined using an oil immersion objective. Spore diameter was measured including the spore wall ornamentation. Microphotographs were taken using a Nikon D7000 digital camera and a Nikon H600L microscope. Voucher specimens and microscope slides are deposited in the Herbarium of the Institute of Botany of the Jagiellonian University in Kraków (KRA MYXO 8874, 8875). 


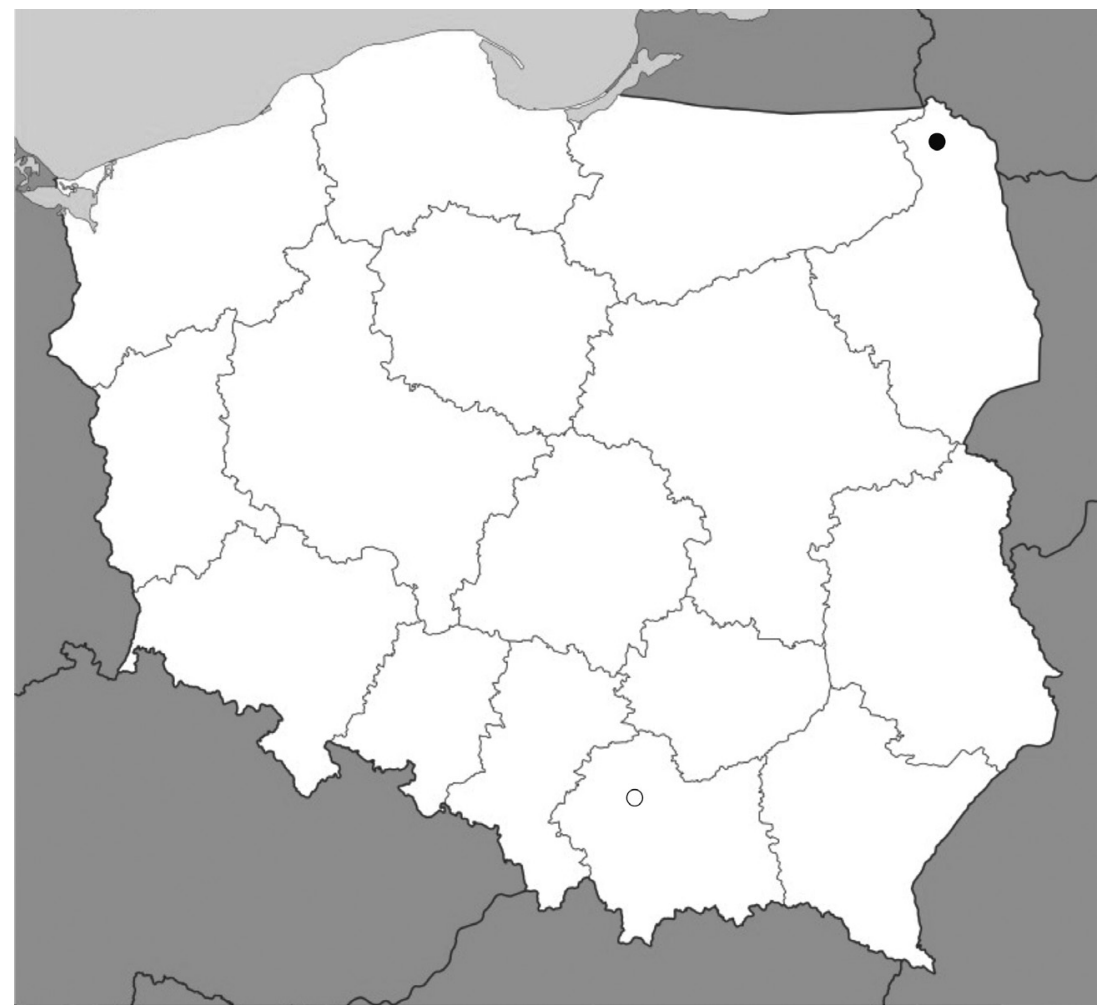

Fig. 1. Distribution of Badhamia versicolor in Poland (province boundaries indicated by grey lines) Explanations: $\bullet-$ new locality, $\circ-$ known locality

\section{Results and discussion}

In August 2016, a new locality of Badhamia versicolor was discovered in the Polish part of the Lithuanian Lakeland, north-eastern Poland. It was found on the edge of the disused sand and gravel pit (formerly, a gravel mine of the Polish State Railway) in the northwestern part of the town of Suwałki, Podlasie Province (GPS coordinates: $54^{\circ} 06.434^{\prime} \mathrm{N}, 22^{\circ} 53.930^{\prime} \mathrm{E}$; altitude: $171 \mathrm{~m}$ a.s.1.). Currently, this is the second record of the species occurrence in Poland (Fig. 1). Two small clusters of mature fruiting bodies of $B$. versicolor were noticed on a bark of living poplar (unidentified alien species of Populus L., which was planted in the pit) and on a fallen leaf of the same poplar tree. The cluster on the bark was composed of 20 sporocarps, whereas the cluster on a dead leaf comprised 48 sporocarps. The area of the pit is exposed to sunlight and drought, especially on its fringes, where it is sparsely covered by vegetation. It is under secondary succession with a significant share of Salix L. species in the central part.

Photographic documentation of B. versicolor is presented in Fig. 2. The diameter of sporocarps was $0.26-0.43 \mathrm{~mm}$, the size of spores was $10-12 \times 9-11 \mu \mathrm{m}$, and the spores were arranged in hollow clusters of 1030. These values of diagnostic features correspond to the description by Poulain et al. (2011), who provided that $B$. versicolor is characterized by its sporocarps of

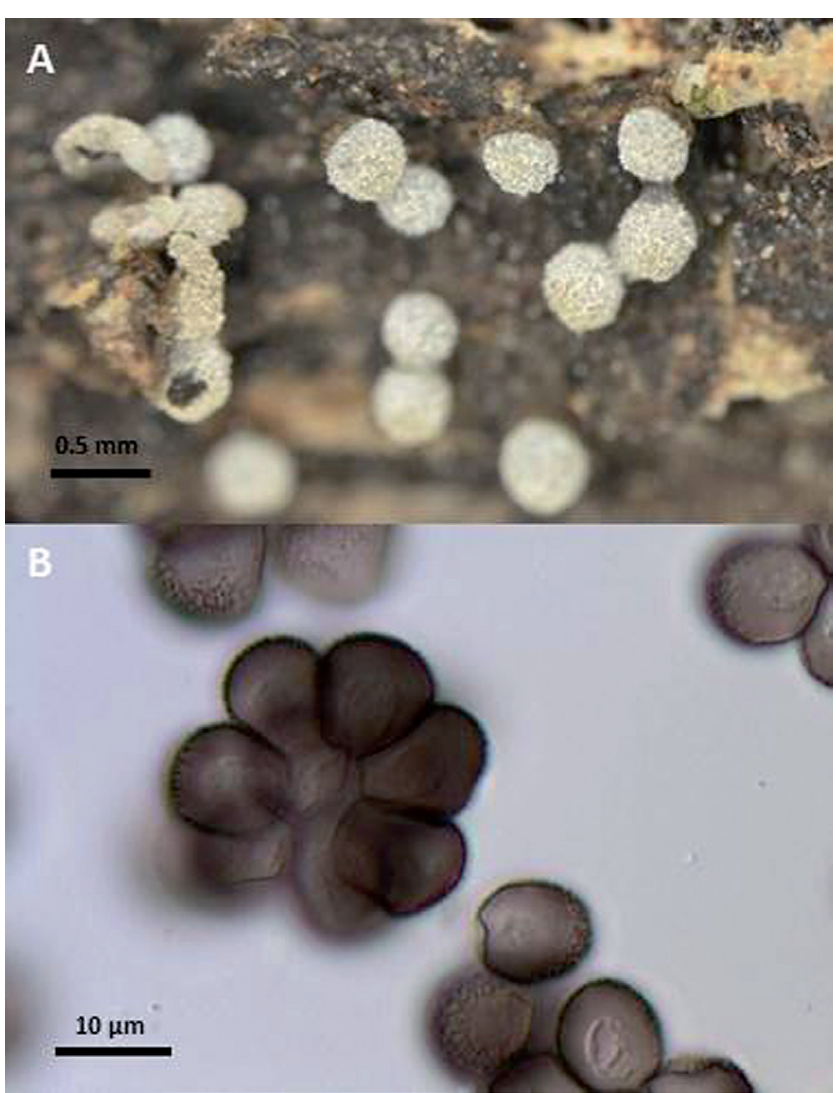

Fig. 2. Photographic documentation of Badhamia versicolor specimens collected in Suwałki

Explanations: A - sporocarps on a bark of poplar, B - spore clusters under the light microscope 
$0.20-0.50 \mathrm{~mm}$ in diameter and spores of $10-14 \times 9-11 \mu \mathrm{m}$ in clusters of 10-60. Moreover, the peridium in the lower part of the sporocarps was yellow, what is considered as one of the most important characters distinguishing $B$. versicolor from $B$. papaveracea (Krzemieniewska 1960). Furthermore, the spores in the examined specimens were warted on the outer surface and smooth elsewhere, whereas in B. papaveracea, the spores are strongly spinose on the outer part and warted or nearly smooth elsewhere (Poulain et al. 2011). Badhamia versicolor is known as a variable species, especially in the coloration of sporocarps and capillitium, as well as in the number of spores in clusters. Interestingly, its calcareous capillitium is white under the lens and apricot-coloured in the water by transmitted light. What is worth mentioning, the capillitium of B. papaveracea, which is a net of lime white tubules, does not show such characteristics (Krzemieniewska 1960; Poulain et al. 2011).
The occurrence of $B$. versicolor on the edge of the disused sand and gravel pit suggests that the species tolerates human-made habitats and is able to thrive in arid areas, as it was observed in Mexico (Estrada-Torres et al. 2009) and Australia (Wellman 2015). Since the disused pits are poorly recognized as habitats suitable for Myxomycetes, a further investigation is needed. In comparison to the data from the Wigry National Park (Panek \& Romański 2010), B. versicolor is a new species for the Polish part of the Lithuanian Lakeland and the sixth species of the genus Badhamia recorded in this region, following B. capsulifera, B. macrocarpa (Ces.) Rostaf., B. panicea (Fr.) Rostaf., B. populina Lister \& G. Lister, and B. utricularis (Bull.) Berk. The rare status of B. versicolor in Poland (Drozdowicz et al. 2006) remains unchanged, however, there is a high probability that new localities will be found in the future.

\section{References}

Abdel-Azeem A. M. \& Salem Fatma M. 2013. A checklist of Egyptian fungi: I. Protozoan fungal analogues. Mycosphere 4: 794-807.

Drozdowicz A., Ronikier A., Stojanowska W. \& Panek E. 2003. Myxomycetes of Poland. A checklist. In: Z. Mirek (ed.). Biodiversity of Poland, 10, 103 pp. W. Szafer Institute of Botany, Polish Academy of Sciences, Kraków.

Drozdowicz A., Ronikier A. \& Stojanowska W. 2006. Red list of rare Myxomycetes in Poland. In: Z. MireK, K. ZARZYCKI, W. WojewOda \& Z. SZELĄG (eds.). Red list of plants and fungi in Poland, pp. 91-99. W. Szafer Institute of Botany, Polish Academy of Sciences, Kraków.

Estrada-Torres A., Wrigley de Basanta D., Conde E. \& LADO C. 2009. Myxomycetes associated with dryland ecosystems of the Tehuacán-Cuicatlán Valley Biosphere Reserve, Mexico. Fungal Divers. 36: 17-56.

Hatano T. \& Keller H. W. 2008. A SEM study of genus Badhamia (Myxomycetes). Bull. Shitennoji Univ. 46: 303-314.

ING B. (ed.). 1982. Provisional atlas of the Myxomycetes of the British Isles. 100 pp. Biological Records Centre, Institute of Terrestrial Ecology, Monks Wood Experimental Station, Huntingdon.

KRZEMIENIEwSKa H. 1960. Śluzowce Polski na tle śluzowców europejskich. 313 pp. PWN, Warszawa.

LADO C. 1991. Catálogo comentado y síntesis corológica de los Myxomycetes de la Península Ibérica e Islas Baleares (1788-1990). Ruizia 9: 1-142.
Macbride T. H. 1922. The North American slime-moulds, a descriptive list of all species of Myxomycetes hitherto reported from the continent of North America with notes on some extra-limited species. $382 \mathrm{pp}$. The Macmilian Company, New York, London.

Moreno G., Castillo A. \& Deschamps J. R. 2013. Critical revision of myxomycetes in the Buenos Aires BAFC herbarium - 1. Mycotaxon 123: 63-79.

Panek E. \& Romański M. 2010. Śluzowce Myxomycetes. In: L. KrzysztofiaK (ed.). Śluzowce Myxomycetes, grzyby Fungi i mszaki Bryophyta Wigierskiego Parku Narodowego, pp. 9-85. Stowarzyszenie "Człowiek i Przyroda", Suwałki.

Poulain M., Meyer M. \& Bozonnet J. 2011. Les Myxomycètes 1 . Guide de détermination. 568 pp. Fédération mycologique et botanique Dauphiné-Savoie, Sévrier.

Raciborski M. 1884. Śluzowce (Myxomycetes) Krakowa i jego okolicy. Kosmos, Ser. A, Biol. 18: 3-11.

Ranade V. D., Korade S. T., Jagtap A. V. \& Ranadive K. R. 2012. Checklist of Myxomycetes from India. Mycosphere 3: 358-390.

Wellman P. 2015. Myxomycetes (slime moulds) of arid to semi-arid areas of northwest New South Wales, Australia. Cunninghamia 15: 153-162.

Wrigley de Basanta D. 1998. Myxomycetes from the bark of the evergreen oak Quercus ilex. Anales Jard. Bot. Madrid 56: 3-14.

www.discoverlife.org 